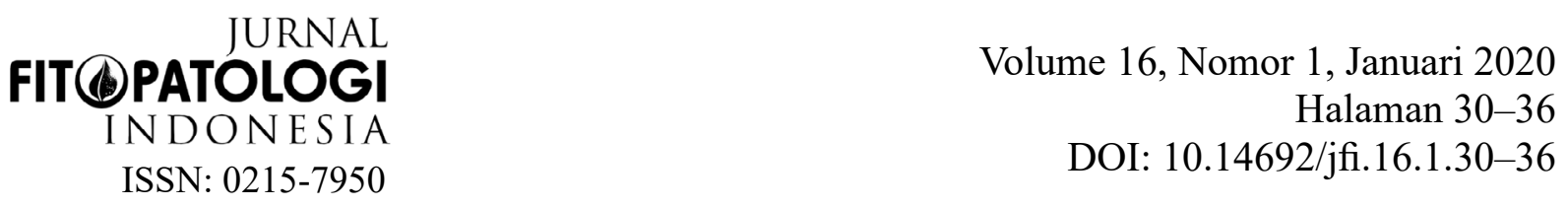

TEMUAN PENYAKIT BARU

\title{
Penyakit Mosaik Kuning Pada Kedelai
}

\author{
Yellow mosaic Disease on Soybean
}

\author{
Mimi Sutrawati ${ }^{*}$, Sri Hendrastuti Hidayat ${ }^{2}$, Gede Suastika ${ }^{2}$, \\ Bonny Poernomo Wahyu Sukarno ${ }^{2}$, Ali Nurmansyah ${ }^{2}$ \\ ${ }^{1}$ Universitas Bengkulu, Bengkulu 38371 \\ ${ }^{2}$ Institut Pertanian Bogor, Bogor 16680
}

\begin{abstract}
ABSTRAK
Ledakan penyakit mosaik kuning yang disebabkan oleh Mungbean yellow mosaic India Begomovirus (MYMIV) terjadi pada tanaman kacang panjang (Vigna unguiculata subsp. sesquipedalis) di Jawa pada 2008. Namun penyakit ini belum dilaporkan di daerah lainnya di Indonesia. Tanaman kedelai di Cirebon, Jawa Barat, Bantul, DI Yogyakarta, dan Musi Banyuasin Sumatera Selatan menunjukkan gejala sistemik berupa mosaik kuning pada daun dengan tulang daun lebih gelap (vein banding) dan diduga terinfeksi MYMIV. Deteksi dan identifikasi virus dilakukan dengan metode polimerase chain reaction (PCR) dengan menggunakan primer spesifik MYMIV. Hasil amplifikasi menghasilkan pita DNA berukuran $1000 \mathrm{pb}$. Hasil ini menunjukkan bahwa tanaman kedelai yang bergejala mosaik kuning dari Cirebon, Bantul, Musi Banyuasin, dan positifterinfeksi MYMIV. Hasil analisis homologi sikuen nukleotida tanaman kedelai yang terinfeksi MYMIV asal Cirebon mempunyai homologi yang tinggi (98.6-99.2 \%) dengan MYMIV dari Tegal, Subang, Klaten, Magelang, Brebes, dan Bogor yang menginfeksi tanaman kacang panjang. Analisis filogenetik menunjukkan bahwa isolat MYMIV Cirebon berada satu kelompok dengan semua sikuen MYMIV di Indonesia dan Oman, namun terpisah dengan kelompok MYMIV dari Bangladesh, Nepal, Pakistan dan India. Sikuen isolat MYMIV Cirebon telah didaftarkan ke GenBank dengan nomor aksesi LC481009. Sebelumnya MYMIV dilaporkan pada kedelai di Jawa tahun 2013. Temuan ini merupakan laporan pertama infeksi MYMIV pada kedelai di luar Jawa (Musi Banyuasin, Sumatera Selatan).

Kata kunci: analisis filogenetik, analisis sikuen, Mungbean yellow mosaic India virus, polymerase chain reaction
\end{abstract}

\begin{abstract}
Epidemic of yellow mosaic disease had occurred in yard long bean (Vigna unguiculata subsp. sesquipedalis) in Java in 2008. However, this disease has never been reported in other areas in Indonesia. Observations on soybean plants in Cirebon (West Java), Bantul (DI Yogyakarta), and Musi Banyuasin (South Sumatra) showed systemic symptoms of yellow mosaic on leaves with vein banding. Plant samples showing yellow mosaic symptoms were taken for virus detection using PCR (polymerase chain reaction). The amplification results with specific MYMIV primers showed 1000 bp DNA bands. The results of analysis nucleotide sequence homology showed MYMIV Cirebon has a high homology (98.6$99.2 \%$ ) with MYMIV from Tegal, Subang, Klaten, Magelang, Brebes, and Bogor. This confirmed that the yellow mosaic symptom leaf samples from Bantul, Musi Banyuasin, and Cirebon were positively
\end{abstract}

\footnotetext{
*Alamat penulis korespondensi: Universitas Bengkulu. Jalan WR. Supratman. Kelurahan Kandang Limun, Kota Bengkulu, 38371.

Tel:+62-732-342584, Surel: mimi_sutrawati@unib.ac.id
} 
infected with MYMIV. Phylogenetic analysis shows that the Cirebon MYMIV isolates formed a group with all MYMIV sequences in Indonesia and Oman, and separated from MYMIV groups from other countries namely Bangladesh, Nepal, Pakistan and India. MYMIV Cirebon isolate was registered in GenBank with accession number LC481009. MYMIV has been reported in soybean in Java (2013). This finding is the first report of MYMIV infection in soybeans in South Sumatera.

Key words: Mungbean yellow mosaic India virus, phylogenetic analysis, polymerase chain reaction, sequence analysis

Tanaman kedelai di Indonesia dilaporkan telah terinfeksi beberapa jenis virus, diantaranya Cowpea mild mottle virus (CPMMV) (Iwaki et al. 1986; Sutrawati et al. 2017), Soybean mosaic virus (SMV) (Andayanie 2013), Cucumber mosaic virus strain kedelai (CMV-S) dan Pepper yellow leaf curl virus (PYLCV) (Rahim et al. 2015). Pada tahun 2014-2015, tanaman kedelai di Cirebon (Jawa Barat), Bantul(DIYogyakarta), dan Musi Banyuasin (Sumatera Selatan) menunjukkan adanya gejala sistemik berupa mosaik kuning, tulang daun menjadi lebih gelap dari pada lamina daun (vein banding) (Gambar 1). Gejala tersebut mirip dengan penyakit mosaik kuning yang pernah dilaporkan terjadi pada tanaman kacang panjang. Penyakit mosaik kuning pada tanaman kacang panjang di Jawa dilaporkan berasosiasi dengan infeksi Bean common mosaic virus (BCMV) (Damayanti et al. 2009) dan Mungbean yellow mosaic India virus (MYMIV) (Nurulita et. al. 2015). Mungbean yellow mosaic India virus merupakan anggota Begomovirus yang ditularkan melalui serangga vektor, yaitu kutukebul Bemisia tabaci Gen. (Hemiptera:
Aleyrodidae) secara persisten sirkulatif (Hull 2014). Selain pada tanaman kacang panjang, beberapa anggota Begomovirus dilaporkan menyebabkan penyakit pada tanaman budi daya lainnya maupun gulma di Indonesia, diantaranya cabai, tomat, gulma Ageratum conyzoides, tembakau, terung dan mentimun (Rusli et al. 1999, Hidayat et al. 2002; Haerani et al. 2003; Hidayat et al. 2008; Kintasari et al.2013; Wiratama et al. 2015). Oleh karena itu, perlu dilakukan deteksi dan identifikasi untuk membuktikan gejala mosaik kuning pada tanaman kedelai terinfeksi virus dari kelompok Begomovirus, untuk mencegah terjadinya epidemi dan pengendalian penyakit tersebut.

Deteksi secara molekuler dilakukan dengan metode PCR (polymerase chain reaction) menggunakan primer spesifik untuk MYMIV (Nurulita et. al. 2015). Tahapan deteksi dilakukan dengan ekstraksi DNA total mengikuti protokol Doyle dan Doyle (1987). Ekstraksi DNA total dilakukan dengan CTAB buffer yang terdiri atas $2 \%$ cetyl trimethylammonium bromide, $1 \%$ polyvinyl pyrrolidone, $100 \mathrm{mM}$ Tris- $\mathrm{HCl}, 1.4 \mathrm{M} \mathrm{NaCl}$, $20 \mathrm{mM}$ EDTA. DNA total diekstraksi dari

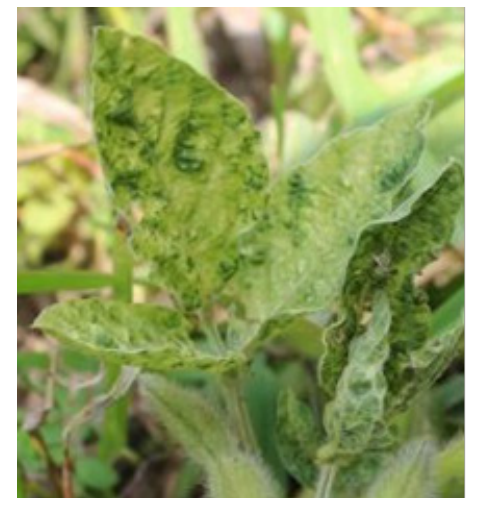

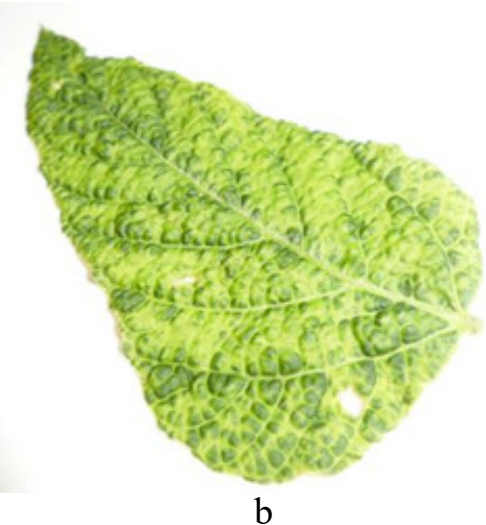

b

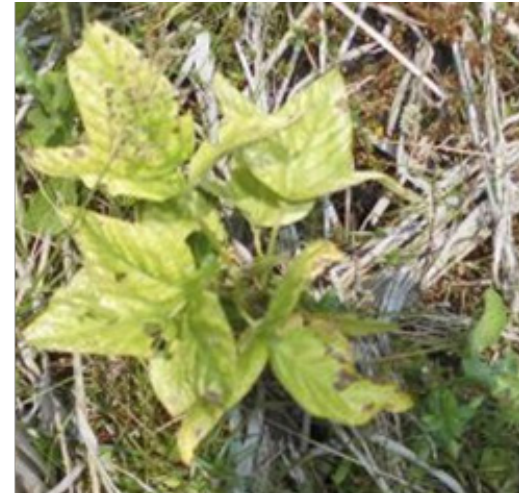

$\mathrm{c}$

Gambar 1 Gejala mosaik kuning pada daun kedelai di beberapa lokasi pengambilan sampel. a, Bantul; b, Cirebon; dan c, Musi Banyuasin. 
$0.1 \mathrm{~g}$ daun kedelai yang digerus di dalam nitrogen cair hingga menjadi serbuk. Serbuk daun selanjutnya dipindahkan ke dalam tabung eppendorf $1.5 \mathrm{~mL}$ yang telah diisi CTAB dan $1 \% \beta$-merkaptoetanol, dilanjutkan dengan inkubasi dalam penangas air pada suhu $65^{\circ} \mathrm{C}$ selama 60 menit, tabung dibolak balik setiap 10 menit. Selanjutnya ditambahkan $500 \mu \mathrm{L}$ kloroform: isoamil alkohol (C:I) dengan perbandingan 24:1 dan dicampur menggunakan vorteks selama 2-5 menit, dilanjutkan dengan sentrifugasi $13000 \mathrm{rpm}$ selama 15 menit. Suspensi akan membentuk beberapa fraksi, kemudian supernatan diambil sebanyak $500 \mu \mathrm{L}$ dan dipindahkan ke dalam tabung eppendorf baru. Sodium asetat sebanyak 1/10 dari total volume supernatan ditambahkan, serta ditambahkan isopropanol (2-propanol) sebanyak 2/3 volume supernatan. Pencampuran suspensi ini dilakukan dengan cara membolak-balikkan tabung eppendorf, dilanjutkan dengan inkubasi pada $-20{ }^{\circ} \mathrm{C}$ selama satu malam. Suspensi yang diperoleh disentrifugasi pada $12000 \mathrm{rpm}$ selama 10 menit dan supernatan dibuang. Pelet yang terbentuk pada dasar tabung, kemudian ditambahkan $750 \mu \mathrm{L}$ etanol $80 \%$ dan disentrifugasi $12000 \mathrm{rpm}$ selama 10 menit. Supernatan dibuang dan pelet dikeringanginkan, lalu diresuspensi dalam $50 \mu \mathrm{L} \mathrm{TE}$. DNA total dapat digunakan untuk tahapan amplifikasi atau disimpan pada $-80{ }^{\circ} \mathrm{C}$ hingga akan digunakan.

Amplifikasi DNA menggunakan primer forward MYF (5'-CCAGCGTAAAAGGCG ACTC-3') dan primer reverse MYR (5'CATGATTCCGGATGCGCAAT-3') (Nurulita et al. 2015). Komposisi reaktan PCR terdiri atas $12.5 \mu \mathrm{L}$ Dream taq PCR master mix 2x 1 (Thermo Scientific), $1 \mu \mathrm{L}$ primer forward $10 \mu \mathrm{M}$, dan $1 \mu \mathrm{L}$ primer reverse $10 \mu \mathrm{M}, 1 \mu \mathrm{L}$ templat DNA, dan $9.5 \mu \mathrm{L} \mathrm{H}_{2} \mathrm{O}$. Amplifikasi DNA dengan tahapan $94{ }^{\circ} \mathrm{C}$ selama 5 menit, dilanjutkan 35 siklus terdiri atas denaturasi (94 ${ }^{\circ} \mathrm{C}$ selama 1 menit), aneling $\left(59-59.5^{\circ} \mathrm{C}\right)$ selama 1 menit, dan sintesis DNA $\left(72{ }^{\circ} \mathrm{C}\right.$ selama 1 menit), selanjutnya tahap ekstensi pada $72{ }^{\circ} \mathrm{C}$ selama 10 menit dan siklus berakhir pada $4{ }^{\circ} \mathrm{C}$. Fragmen DNA hasil amplifikasi dielektroforesis dalam $1 \%$ gel agarosa menggunakan $0.5 x$ TBE pada tegangan 50 Volt selama 50 menit. Hasil elektroforesis divisualisasi dengan $U V$ transilluminator dan didokumentasikan.

Produk amplifikasi diproses untuk perunutan nukleotida di FirstBASE Laboratories (Malaysia). Analisis sikuen nukleotida diawali dengan tahap penyejajaran sikuen sampel penelitian dengan sikuen nukleotida MYMIV lainnya yang terdapat di GenBank dengan tujuan untuk mengonfirmasi identitas MYMIV dari sampel. Analisis keragaman genetik MYMIV, dilakukan melalui program Bio Edit versi 7.05 (http:// mbio.ncsu.edu/BioEdit/bioedit.html). Analisis homologi MYMIV melibatkan informasi yang tersedia dalam GenBank, yaitu sikuen isolat MYMIV dari beberapa daerah di Indonesia dan dari beberapa negara (Tabel 1).

Analisis homologi sikuen nukleotida dilakukan menggunakan software ClustalW (www.ebi.ac.uk). Pohon filogenetik MYMIV dikonstruksi menggunakan program ClustalX Bio Edit versi 7.05 dan program MEGA 5.0 dengan metode neighbor-joining algorithm dan bootstrap 1000 pengulangan.

Amplifikasi DNA sampel daun kedelai bergejala mosaik kuning dari Cirebon-Jawa Barat,Bantul-Yogyakarta, danMusiBanyuasinSumatera Selatan menggunakan primer MYF/MYR menghasilkan pita DNA spesifik MYMIV berukuran 1000 pb (Gambar 2). Hasil amplifikasi ini menunjukkan bahwa sampel daun kedelai dengan gejala mosaik kuning dari Cirebon, Bantul, dan Musi Banyuasin positif terinfeksi MYMIV (Gambar 2). Analisis homologi sikuen nukleotida MYMIV dari Cirebon mempunyai homologi yang sangat tinggi (98.6-99.2\%) dengan MYMIV dari Tegal, Subang, Klaten, Magelang, Bogor, dan Brebes. Homologi MYMIV isolat Cirebon juga menunjukkan homologi tinggi dengan isolat dari negara Oman, Pakistan, India, Nepal, dan Bangladesh (82.6-97.9\%) (Tabel 2). Sikuen isolat MYMIV kedelai dari Cirebon sudah didaftarkan pada basis data Genbank, dengan nomor aksesi LC481009. Penelitian ini memberi informasi bahwa penyakit mosaik kuning pada kedelai 
Tabel 1 Daftar sikuen nukleotida MYMIV dan Begomovirus lainnya pada GenBank yang digunakan untuk analisis sikuen nukleotida

\begin{tabular}{lcc}
\hline \multirow{2}{*}{ No aksesi (virus) } & \multicolumn{2}{c}{ Asal isolat } \\
\cline { 2 - 3 } LC114252 (MYMIV) & Negara (daerah) & Tanaman inang \\
KR021041(MYMIV) & Indonesia (Bogor) & Vigna unguiculata subsp. unguiculata \\
LC114255(MYMIV) & Indonesia (Klaten) & V. unguiculata subsp. unguiculata \\
LC114256 (MYMIV) & Indonesia (Subang) & V. unguiculata subsp. sesquipedalis \\
LC114254 (MYMIV. sesquipedalis \\
JN368439 (MYMIV) & Indonesia (Tegal) & V. unguiculata subsp. sesquipedalis \\
KX452228 (MYMIV) & Indonesia (Brebes) & Glyicine max \\
AY269992 (MYMIV) & Oman & Phaseolus vulgaris \\
KC911720 (MYMIV) & Pakistan & Vigna radiata \\
AY271895 (MYMIV) & India & Vigna mungo \\
AF314145 (MYMIV) & Nepal & Vigna radiata \\
LC314795 (PepYLCIV) & Bangladesh & Vigna radiata \\
JN129254 (ToLCNDV) & Indonesia & Capsicum annuum \\
\hline
\end{tabular}

Tabel 2 Homologi sikuen nukleotida MYMIV Cirebon dengan MYMIV lainnya di Indonesia dan beberapa negara di GenBank

\begin{tabular}{lcc}
\hline No aksesi GenBank & Homologi (\%) & Query cover (\%) \\
\hline LC114252.MYMIV.ID_Bogor & 99.20 & 100 \\
KR021041.MYMIV.ID_Magelang & 99.20 & 100 \\
LC114255.MYMIV.ID_Klaten & 98.90 & 100 \\
LC114256.MYMIV.ID_Subang & 98.80 & 100 \\
LC114254.MYMIV.ID_Tegal & 98.60 & 100 \\
JN368439.MYMIV.ID_Brebes & 99.20 & 100 \\
KX452228.MYMIV.Oman & 97.90 & 100 \\
AY269992.MYMIV.Pakistan & 94.40 & 100 \\
KC911720.MYMIV.India & 93.50 & 99 \\
AY271895.MYMIV.Nepal & 93.50 & 100 \\
AF314145.MYMIV.Bangladesh & 82.60 & 100 \\
LC314795.PepYLCIV & 27.40 & 28 \\
JN129254.ToLCNDV & 57.80 & 44 \\
\hline
\end{tabular}

berasosiasi dengan MYMIV. Laporan ini menambahkan informasi sebelumnya mengenai infeksi MYMIV pada kedelai di Brebes (Tsai et al. 2013). Sementara Rahim et al. (2015) menggunakan general primer SPG1/ SPG2 untuk Geminivirus dan menyatakan gejala mosaik kuning pada kedelai disebabkan oleh Pepper yellow leaf curl virus (PYLCV).

Analisis filogenetika untuk mengetahui kekerabatan antar sikuen MYMIV menunjukkan bahwa MYMIV Cirebon (nomor aksesi LC481009) membentuk satu kelompok dengan semua sikeun MYMIV Jawa, dan terpisah dengan kelompok MYMIV dari negara

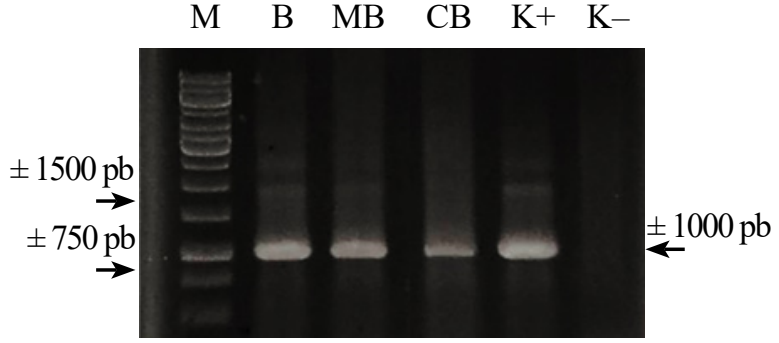

Gambar 2 Amplifikasi DNA MYMIV dari sampel tanaman kedelai asal Bantul (B), Musi Banyuasin (MB) dan Cirebon (CB). M, $1 \mathrm{~kb}$ penanda DNA (Thermo Scientific); $\mathrm{K}+$, kontrol positif (sampel kacang panjang); $\mathrm{K}-$, kontrol negatif (air). 


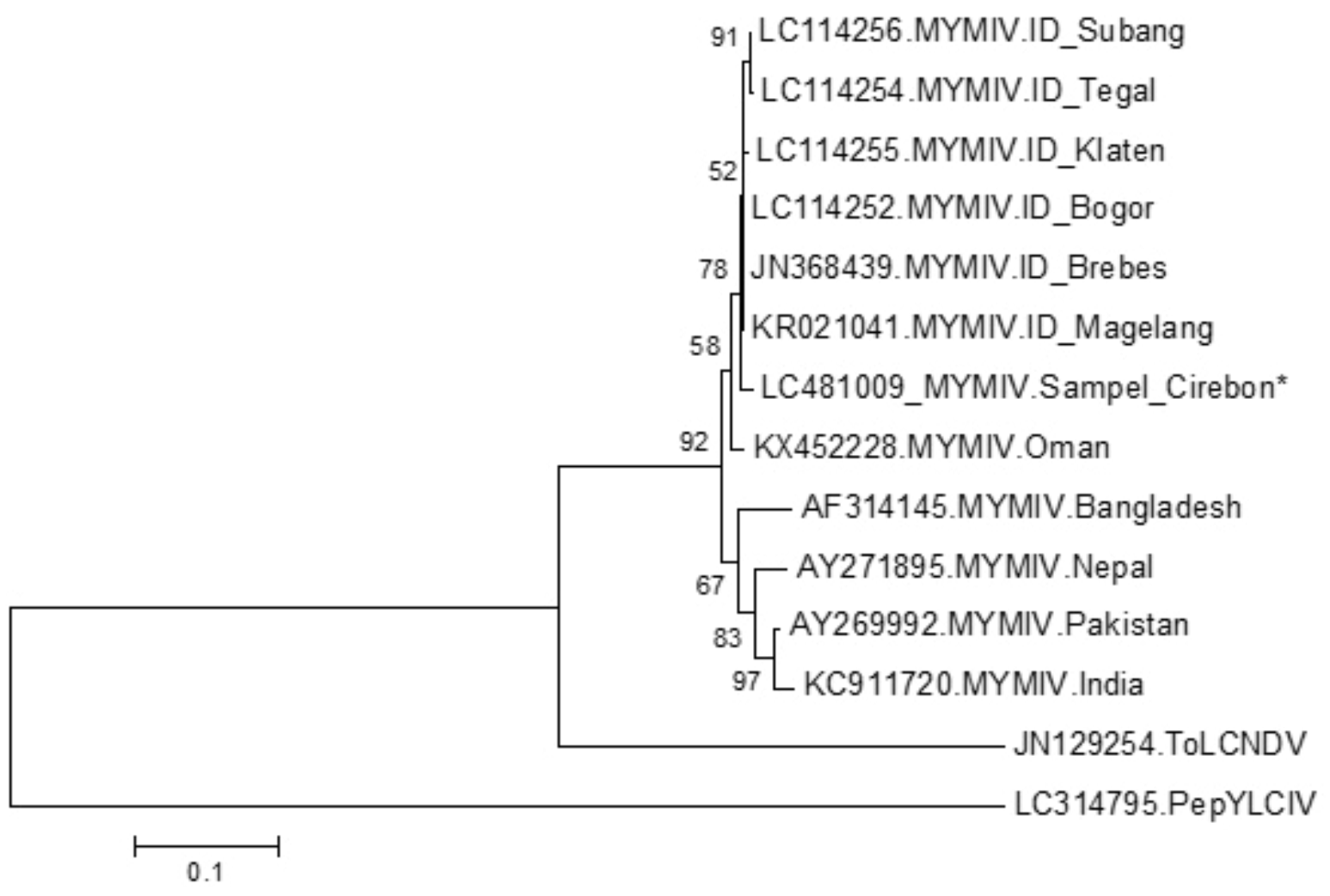

Gambar 3 Pohon filogenetika MYMIV asal kedelai dari Cirebon (LC481009) dibandingkan dengan isolat asal Subang, Tegal, Klaten, Bogor, Brebes, Magelang serta Oman, Bangladesh, Nepal, Pakistan, India. TolCNDV dan PepYLCV sebagai outgroup.

lain, yaitu Bangladesh, Nepal, Pakistan, dan India(Gambar3). King et al. (2011) menjelaskan pengelompokkan Begomovirus berdasarkan distribusi geografis diduga terkait dengan isolasi geografis karena ketidakmampuan serangga vektornya terbang jauh.

Mungbean yellow mosaic India virus pertama kali dilaporkan menginfeksi tanaman Phaseolus vulgaris di Pakistan dengan insidensi penyakit $70-100 \%$ (Naimuddin et al. 2011), dan Vigna mungo di Nepal dengan insidensi penyakit mencapai $70-80 \%$ (Shahid et al. 2012). Baru-baru ini MYMIV dilaporkan menginfeksi Phaseolus vulgaris di Oman (Shahid et al. 2016). Mungbean yellow mosaic india virus dan Mungbean yellow mosaic virus (MYMV) dilaporkan menimbulkan kerugian pada beberapa spesies Leguminoceae di wilayah selatan dan barat India, sedangkan MYMIV dilaporkan menginfeksi Leguminoceae di wilayah India bagian utara dan tengah (Mandal et al. 1997), serta Pakistan (Ilyas et al. 2010). John et al.(2008) melaporkan bahwa penyakit mosaik kuning di India berasosiasi dengan MYMIV, namun analisis sikuen komponen DNA B MYMIV menunjukkan homologi yang tinggi dengan Begomovirus lainnya yang menginfeksi Leguminoceae di daerah tersebut, yaitu Mungbean yellow mosaic virus (MYMV).

Infeksi MYMIV dilaporkan sebelumnya menimbulkan kerusakan pada kacang panjang di berbagai daerah di pulau Jawa (Nurulita 2015). MYMIV pada kedelai telah dilaporkan di Brebes (Tsai et al. 2013). Laporan ini menunjukkan MYMIV terdeteksi pada kedelai di daerah lainnya, yaitu Bantul, Cirebon, Musi Banyuasin. Infeksi MYMIV pada tanaman kedelai di berbagai daerah menjadi fakta bahwa MYMIV telah tersebar ke luar pulau Jawa dan berpotensi memiliki kisaran inang yang cukup luas sehingga perlu diperhatikan untuk mengantisipasi kerugian hasil panen yang semakin besar. 


\section{DAFTAR PUSTAKA}

Andayanie WR. 2013. Diagnosis penyakit mosaik (Soybean mosaic virus) terbawa benihkedelai.JHPTTropika.12(2):185-191.

Damayanti TA, Alabi OJ, Rauf A, Naidu RA. 2009. Severe outbreak of yellow mosaic disease on the yard long bean in Bogor, West Java. Hayati J of Biosci 16(2):78-82. DOI: https://doi.org/10.4308/hjb.16.2.78.

Doyle JJ, Doyle JJ. 1987. Arapid DNA isolation of proceduren for small quantities of fresh leaf tissue. Phytochem Bull. 19:11-19.

Haerani, Hidayat SH. 2003. Geminivirus penyebab penyakit kuning pada babadotan (Ageratum conyzoides): deteksi molekuler dan studi penularan pada beberapa tanaman Solanaceae. J Fitopatol Indones. $7(2): 65-70$.

Hidayat SH. Chatchawankopanich O, Aidawati N. 2008. Molecular identification and sequence analysis of tobacco leaf curl Begomovirus from Jember, East Java, Indonesia. Hayati J of Biosc. 15(1):13-17. DOI: https://doi.org/10.4308/hjb.15.1.13.

Hidayat SH, Mulyati S, Kadir M, Sulandari S, Aidawati N. 2002. Tobacco leaf curl virus from Indonesia: its detection and host range study. J Agrik. 13:157-161.

Hull R. 2014. Plant Virology. London (UK): Academic press.

Ilyas M, Qazi J, Mansoor S, Briddon RW. 2010. Genetic diversity and phylogeography of Begomoviruses infecting legumes in Pakistan. J Gen Virol. 91:2091-2101. DOI: https://doi.org/10.1099/vir.0.020404-0.

Iwaki $\mathrm{M}$, Thongmeearkom $\mathrm{P}$, Honda $\mathrm{Y}$, Prommin M, Deema N, Hibi T, Iizuka N, Ong C, Saleh N. 1986. Cowpea mild mottle virus occurring on soybean and peanut in Southeast Asian countries. Trop Agric Res Centre. (21):106-120.

John P, Silvalingam PN, Haq QMI, Kumar N, Mishra A, Briddon RW, Malathi VG. 2008. Cowpea golden mosaic disease in Gujarat is caused by a Mungbean yellow mosaic India virus isolate with a DNA B variant. Arch Virol. 153:1359-1365. DOI: https:// doi.org/10.1007/s00705-008-0116-8.
King AM, Lefkowitz E, Adams MJ, Carstens EB. 2011. Virus taxonomy: ninth report of the International Committee on Taxonomy of Viruses, Vol. 9. San Diego (US): Elsevier. Kintasari T, Septariani DWN, Sulandari S, Hidayat SH. 2013. Tomato leaf curl Kanchanaburi virus penyebab penyakit mosaik kuning pada tanaman terung di Jawa. J Fitopatol Indones. 9(4):127-131. DOI: https://doi.org/10.14692/jfi.9.4.127.

Mandal B, Varma A, Malathi VG. 1997. Systemic infection of Vigna mungo using the cloned DNAs of the blackgram isolate of mungbean yellow mosaic geminivirus through agroinoculation and transmission of the progeny virus by whiteflies. J Phytopathol. 145:503-510. DOI: 1https:// doi.org/10.1111/j.1439-0434.1997. tb00358.x.

Naimuddin, Akram M, Pratap A. 2011. First report of natural infection of Mungbean yellow mosaic India virus in two wild species of Vigna. New Dis Rep. 23:21. DOI: https://doi.org/10.5197 /j.2044-0588.2011.023.021.

Nurulita S, Hidayat SH, Mutaqin KH, Thomas J. 2015. Molecular characterization of Begomovirus infecting yard long bean (Vigna unguiculata subsp. sesquipedalis L.) in Java, Indonesia. BIOTROPIAThe Southeast Asian Journal of Tropical Biology. 22(1):53-60. DOI: https://doi. org/10.11598/btb.2015.22.1.401.

Rahim YF, Damayanti TA, Ghulamahdi M. 2015. Deteksi virus yang menginfeksi kedelai di Jawa. J Fitopatol Indones. 11(2):68-72. DOI: https://doi. org/10.14692/jfi.11.2.59.

Rusli ES, Hidayat SH, Suseno R, Tjahjono B. 1999. Virus Gemini asal cabai: kisaran inang dan cara penularan. Bulletin HPT 11:26-31.

Shahid MS, Pudashini BJ, Khatri-Chhetri GB, Ikegami M, Natsuaki KT. 2012. First report of kidney bean in Nepal. New Dis Rep. 25:30. DOI: https://doi.org/10.5197 /j.2044-0588.2012.025.030.

Shahid MS, Briddon RW, Al-Saidi AM. 2016. Identification of Mungbean yellow mosaic 
Indian virus associated with tomato leaf curl betasattelite infecting Phaseolus vulgaris. Oman J Phytopath. 165:204-211. DOI: https://doi.org/10.1111/jph.12551.

Sutrawati M, Hidayat SH, Soekarno BPW, Nurmansyah A, Suastika G. 2017. Kisaran inang Cowpea mild mottle virus dan respons varietas kedelai. J Fitopatol Indones. 13(6):229-237. DOI: https://doi. org/10.14692/jfi.13.6.229

Tsai WS, Shih SL, Rauf A, Safitri R, Hidayati N, Huyen BTT, Kenyon L. 2013. Genetic diversity of legume yellow mosaic begomoviruses in Indonesia and Vietnam. Ann Apl Biol. 163:367-377. DOI: https:// doi.org/10.1111/aab.12063.

Wiratama IDMP, Wirya GNAS, Adnyani NNP, Nyana IDNN, Suastika G. 2015. Laporan pertama infeksi Begomovirus pada tanaman mentimun di Bali. J Fitopatol Indones. 11(5):175-178. DOI: https://doi. org/10.14692/jfi.11.5.175. 